\title{
Performance assessment, in terms of ripples and power, of conventional and interleaved converter DC-DC with coupled and independent inductors dedicated to photovoltaic installations
}

\author{
Brahim Lagssiyer, Aziz Abdelhak, Mohamed El Hafyani \\ Laboratory of Electrical Engineering and Maintenance, High School of Technology, University Mohammed I, Morocco
}

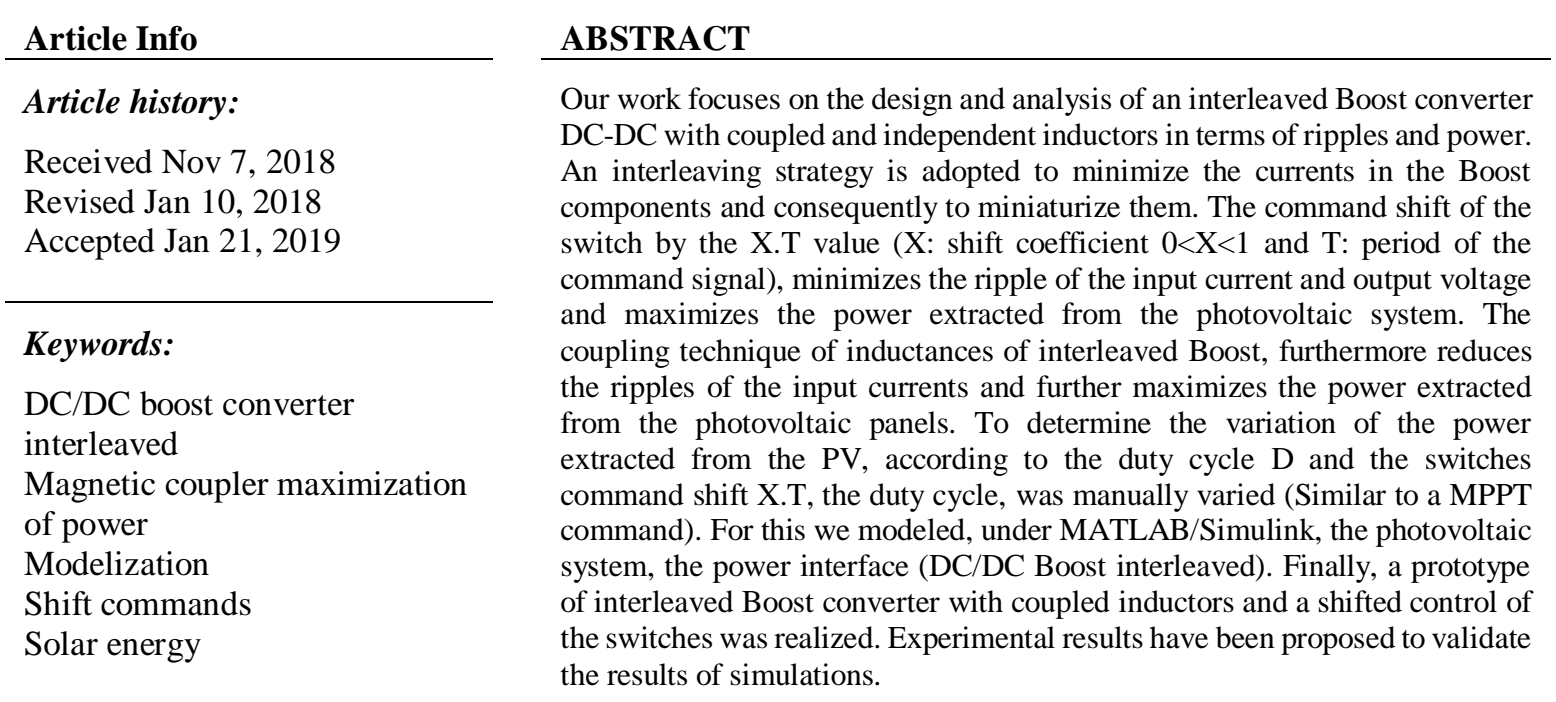

Copyright $(0) 2019$ Institute of Advanced Engineering and Science. All rights reserved.

\section{Corresponding Author:}

Brahim Lagssiyer,

Laboratory of Electrical Engineering and Maintenance,

High School of Technology, University Mohammed I,

BV Mohammed VI B.P. 524, Oujda 60000.

Email: Lagssiyer.B@gmail.com

\section{INTRODUCTION}

Renewable energy sources such as photovoltaic cells, fuel cells, wind energy. etc., is one of the most reliable remedies for saving electrical energy [1]-[3]. These sources require an energy conditioning system. Indeed, the voltages and currents produced by photovoltaic panels need to be improved in terms of ripples quality and efficiency [4], [5].

A conventional DC-DC Boost converter is often used as an interface converter. However, in applications requiring high-density power, such as electric vehicles, hybrid electric vehicles [8] and photovoltaic, interleaved boost converters are the most suitable solution. Several articles reported in the literature [6]-[10], have highlighted the advantages of these topologies compared to other topologies developed for photovoltaic applications.

Indeed, these topologies have many advantages in terms of power quality extracted from PV, energy efficiency, reduction of input current ripple, dynamic response, simple design, robustness and stable condition. As part of this work, and for optimization objectives in terms of maximizing the power extracted from PV, miniaturization of electronic components [11], reduction of input current ripple and output voltage, it was 
chosen to focus on a two-branches interleaved DC/DC Boost converter, with and without inductance coupling compared to a conventional Boost converter [12]-[14].

In order to verify the reliability level of this converter as a function of different duty cycle values, D (duty cycle) was varied from 0 to 1 , similar to an MPPT algorithm. A shift of the XT value of the switch commands, and a coupling of the inductors is shown in Figure 3 enabled us to improve the performance of the interleaved Boost converter with inductors coupling, in terms of energy efficiency and input current ripple [15], [16].

This article is divided into 5 parts: The part (I) focuses on the Boost converters, the part (II) describes the interleaving and coupling technique of the proposed Boost converter, the part (III) illustrates the results of the simulations, while the part (VI) presents the results of the measurements, in the end, part (V), we present the conclusion and the future perspectives.

\section{BOOST CONVERTER (DC-DC)}

\subsection{Classic DC-DC Boost Converter}

DC-DC Boost converters are power modulation circuits. They generate a variable DC voltage as a function of the duty cycle D and the input voltage Ve. They consist of capacitors (Cs), inductors (L) and switches (Mosfet) in blocked saturated mode as shown in Figure 1 [1], [17], [18], [19].

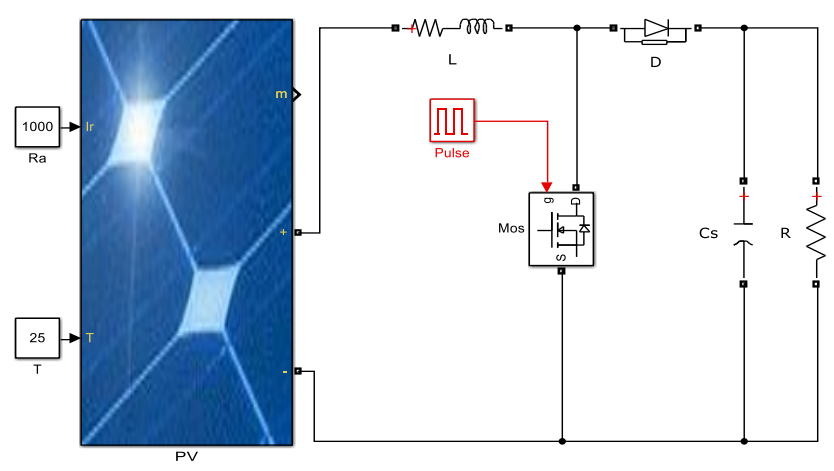

Figure 1. Classic converter boost

The ripple of the input current $\Delta \mathrm{ie}_{\mathrm{Cl}}$ of a conventional Boost converter. It is given by (1):

$$
\Delta \mathrm{ie}_{\mathrm{Cl}}=\frac{\text { D. } \mathrm{V}_{\mathrm{e}}}{\text { L.f }}
$$

The undulation of the terminal voltage of the load also depends on the duty cycle D and output capacitance $\mathrm{C}_{\mathrm{S}}$. It is given by the (2):

$$
\Delta \mathrm{Vs}_{\mathrm{Cl}}=\frac{\text { D.Is }}{\mathrm{C}_{\mathrm{s}} \cdot \mathrm{f}}
$$

$\Delta \mathrm{V}_{\mathrm{S}_{\mathrm{Cl}}}$ : output voltage ripple of a classic Boost.

Is: output current.

f: Frequency.

\subsection{Interleaved DC-DC Boost Converter}

The interleaved DC-DC Boost converter consists in connecting in parallel two or more conventional Boost converters with the same characteristics of these components $\left(\mathrm{L}=\mathrm{L}_{1}=\mathrm{L}_{2}\right)$ as shown in Figure 2 . They are used in applications of strong currents: photovoltaic installations, power of the microprocessors of the computers, high power emergency inverters, electric car [20], [21], [22].

Each elementary Boost is controlled by the same value of the duty cycle D, while the commands are shifted between them by a value X.T (T: period, X: shift coefficient) [1], [3]. 


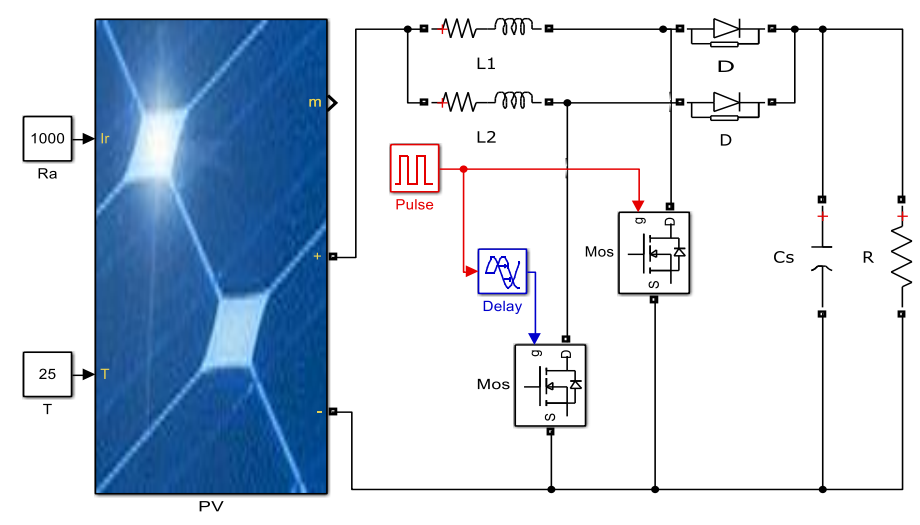

Figure 2. Interleaved converter boost with two independent branches

The input current ripple $\Delta \mathrm{i}_{\mathrm{Ent}}$ for an interleaved Boost converter, without coupling of the inductances, is given $[1,3]$ :

For a duty cycle $\mathrm{D}<0.5$ and $\mathrm{X}=0.5$ :

$$
\begin{aligned}
\Delta \mathrm{ie}_{\mathrm{Ent}} & =\frac{\mathrm{D} \cdot \mathrm{V}_{\mathrm{e}}}{\mathrm{L} \cdot \mathrm{f}} \cdot \frac{1-2 . \mathrm{D}}{1-\mathrm{D}} \\
& =\Delta \mathrm{ie}_{\mathrm{Cl}} \cdot \frac{1-2 . \mathrm{D}}{1-\mathrm{D}}
\end{aligned}
$$

For a duty cycle $\mathrm{D}>0.5$ and $\mathrm{X}=0.5$ :

$$
\begin{aligned}
\Delta \mathrm{ie}_{\mathrm{Ent}} & =\frac{\mathrm{D} \cdot \mathrm{V}_{\mathrm{e}}}{\mathrm{L} \cdot \mathrm{f}} \cdot \frac{2 \cdot \mathrm{D}-1}{\mathrm{D}} \\
& =\Delta \mathrm{ie}_{\mathrm{Cl}} \cdot \frac{2 \cdot \mathrm{D}-1}{\mathrm{D}}
\end{aligned}
$$

From (3) and (4), we deduce that for the same inductance value of the interleaved Boost converter without coupling of the inductors, the ripple of the input current $\Delta \mathrm{ie}_{\mathrm{Ent}}$ is small, compared to that of a classical Boost $\Delta \mathrm{ie}_{\mathrm{Cl}}$.

The ripple of the voltage across the load, connected to the interleaved Boost without coupling of inductances, is given by (5) [1]:

$$
\begin{aligned}
\Delta \mathrm{Vs}_{\mathrm{Ent}} & =\frac{\mathrm{Is}}{\mathrm{C}_{\mathrm{s}} \cdot \mathrm{f}} \cdot|\mathrm{D}-0.5| \\
& =\Delta \mathrm{Vs}_{\mathrm{Cl}} \cdot \frac{|\mathrm{D}-0.5|}{\mathrm{D}}
\end{aligned}
$$

With:

$\Delta \mathrm{Vs}_{\mathrm{Cl}}$ : output voltage ripple of a classic Boost.

$\Delta \mathrm{VS}_{\mathrm{En}} \mathrm{t}$ : output voltage ripple of interleaved Boost.

$\mathrm{C}_{\mathrm{S}}$ : output capacitance.

According to (5), the ripple of the output voltage of the interleaved Boost without coupling of the inductors $\Delta \mathrm{VS}_{\mathrm{Ent}}$, is low compared to that of the conventional Boost $\Delta \mathrm{Vs}_{\mathrm{Cl}}$ for the same output capacitance $\mathrm{C}_{\mathrm{S}}$.

\subsection{Interleaved DC-DC Boost Converter with Coupled Inductance}

The inductors coupling of interleaved Boost converters, consists in magnetically connecting the inductances via a magnetic coupler [23]-[25].

In this article, we have opted for a structure of the interleaved converter with two coupled branches as shown in Figure 3. 


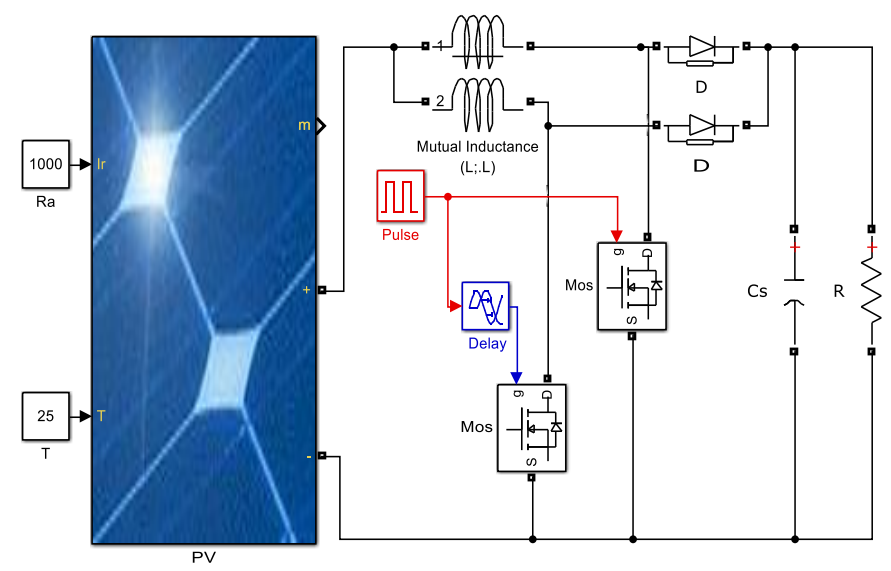

Figure 3. Interleaved converter with two coupled branches

\subsubsection{Input Current Ripple $\Delta$ iepv}

The two branches of the converter are identical. The currents in the inductances are of the same shape. They are shifted by X.T value between them.

According to (1), the ripple of the current in each inductor are always equal (6) [2], [3]:

$$
\Delta i_{L 1}=\Delta i_{L 2}=\frac{D \cdot V_{e}}{L_{1} \cdot f}=\frac{D \cdot V_{e}}{L_{2} \cdot f}=\frac{D \cdot V_{e}}{L \cdot f}
$$

With:

Ve: input voltage

f: frequency

D: duty cycle

$\mathrm{X}$ : shift coefficient

$\mathrm{T}$ : period of the command signal

We choose the inductors $\mathrm{L}_{1}=\mathrm{L}_{2}=\mathrm{L}$, the voltage across the inductors $\mathrm{V}_{\mathrm{L}}$. It is given by (7):

$$
\begin{aligned}
& V_{L 1}=L \frac{d i_{1}}{d t}+M \frac{d i_{2}}{d t} \\
& V_{L 2}=M \frac{d_{1}}{d t}+L \frac{d i_{2}}{d t}
\end{aligned}
$$

With:

$\mathrm{M}=\mathrm{k} . \mathrm{L} \quad$ and $-1<\mathrm{K}<1$

M: mutual between inductances

$\mathrm{K}$ : coefficient of coupling.

The input current ripple $\Delta \mathrm{ie}_{\mathrm{EntC}}$, of interleaved Boost converter with coupled inductors, is a function of the duty cycle $\mathrm{D}$, the shift of commands $\mathrm{X}$ and the coupling coefficient $\mathrm{K}$. It is given:

For a duty cycle $\mathrm{D}<0.5$ and $\mathrm{X}=0.5$

$$
\begin{aligned}
\Delta \mathrm{ie}_{\text {EntCo }} & =\frac{D \cdot V_{\mathrm{e}}}{\mathrm{L} . \mathrm{f}} \cdot \frac{1-2 \cdot \mathrm{D}}{1-\mathrm{D}} \cdot \frac{1}{1+\mathrm{K}} \\
& =\Delta \mathrm{ie}_{\mathrm{Ent}} \cdot \frac{1}{1+\mathrm{K}}
\end{aligned}
$$

For a duty cycle $\mathrm{D}>0.5$ and $\mathrm{X}=0.5$

$$
\begin{aligned}
\Delta \mathrm{ie}_{\text {EntCo }} & =\frac{\mathrm{D} \cdot \mathrm{V}_{\mathrm{e}}}{\mathrm{L} \cdot \mathrm{f}} \cdot \frac{2 \cdot \mathrm{D}-1}{\mathrm{D}} \cdot \frac{1}{1+\mathrm{K}} \\
& =\Delta \mathrm{ie}_{\mathrm{Ent}} \cdot \frac{1}{1+\mathrm{K}}
\end{aligned}
$$


Based on the (8) and (9), it is deduced that the coupling of the inductors of the interleaved Boost minimizes the ripple of the input current $\Delta \mathrm{ie}_{\mathrm{EntCo}}$ by $\frac{1}{1+K}$ compared to that of interleaved Boost without coupling of the inductances $\Delta \mathrm{ie}_{\mathrm{Ent}}$ for the same value of the inductance $\mathrm{L}$.

\subsubsection{Output Voltage Ripple $\Delta V_{S}$}

The output voltage undulation $\Delta \mathrm{VS}_{\mathrm{EntCo}}$ of the interleaved Boost with coupling of the inductances, is a function of the duty cycle $\mathrm{D}$, the command shift $\mathrm{X}$ and the output capacitance $\mathrm{C}_{\mathrm{S}}$. It is given (10):

$$
\begin{aligned}
\Delta \mathrm{Vs}_{\text {EntCo }} & =\frac{\mathrm{Is}}{\mathrm{C}_{\mathrm{S}} \cdot \mathrm{f}}|\mathrm{D}-0.5| \\
& =\Delta \mathrm{Vs}_{\mathrm{Ent}}
\end{aligned}
$$

With:

$\Delta \mathrm{VS}_{\mathrm{Cl}}$ : output voltage ripple of a classic Boost.

$\Delta \mathrm{VS}_{\mathrm{Ent}}$ : output voltage ripple of interleaved Boost.

According to (10), the coupling of the inductors does not allow any reduction of the output voltage ripples of the interleaved Boost for the same value of output capacitance Cs.

\section{SIMULATION}

Based on DC/DC converters structures, numerical simulations, both conventional and interlaced converters, were realized under the Matlab/Simulink® software is shown in Figure 1, Figure 2 and Figure 3 for different values of the duty cycle D and shift switch commands X. The parameters of the studied system are given in Table 1.

Table 1. Parameters of the Simulation System

\begin{tabular}{cc}
\hline PV System & Values) \\
\hline PV Power (P) & $180 \mathrm{~W}$ \\
Nominal voltage of the PV (Vpv) & $24.4 \mathrm{~V}$ \\
Nominal current of the PV (Ipv) & $7.5 \mathrm{~A}$ \\
Switching frequency (f) & $13.5 \mathrm{KHz}$ \\
Load (R) & $20 \Omega$ \\
Output capacitance (Cs) & $220 \mu \mathrm{F}$ \\
Inductors (L1=L2=L) & $433.47 \mu \mathrm{H}$ \\
Coupling coefficient (K) & 0.93 \\
\hline
\end{tabular}

\subsection{Switch Control Signal}

Figure 4 illustrates the commands of the switches which are of the same frequency but they are shifted between them by a value X.T (T: period, X: shift coefficient).

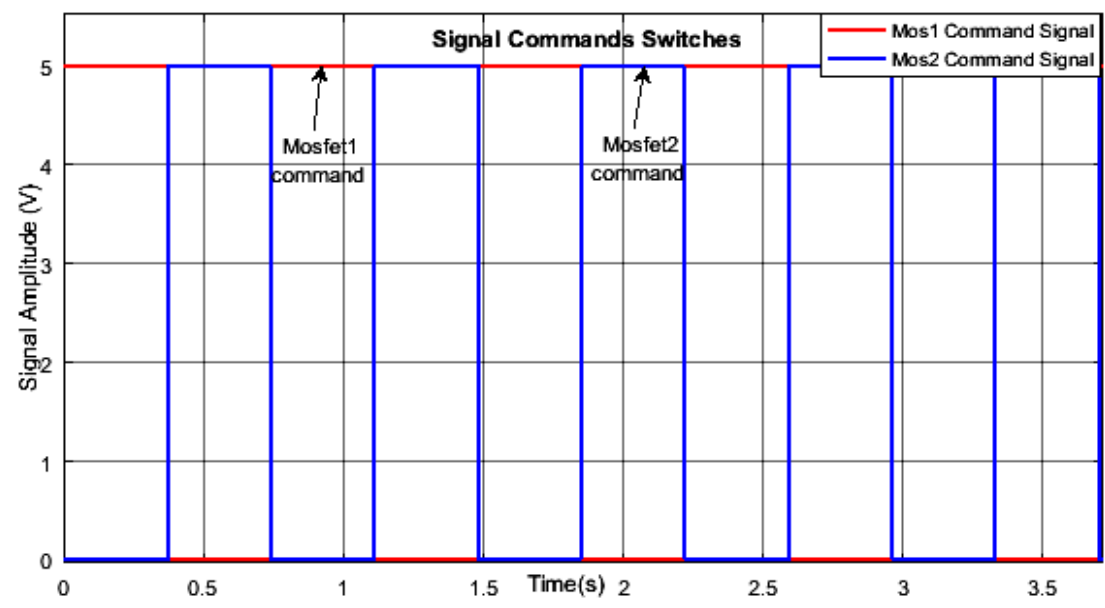

Figure 4. Switch commands with shift coefficient $X=0.5$ 


\subsection{Input Current Ripples $\Delta$ ie}

In Figure 5, we simulated the input current ripple $\Delta \mathrm{ie}$ of the photovoltaic panel, connected to a conventional and interleaved Boost, with coupled and independent inductances, for different values of the duty cycle $\mathrm{D}(0<\mathrm{D}<1)$ similar to a control MPPT, with shift of switch commands $\mathrm{X}=05$.

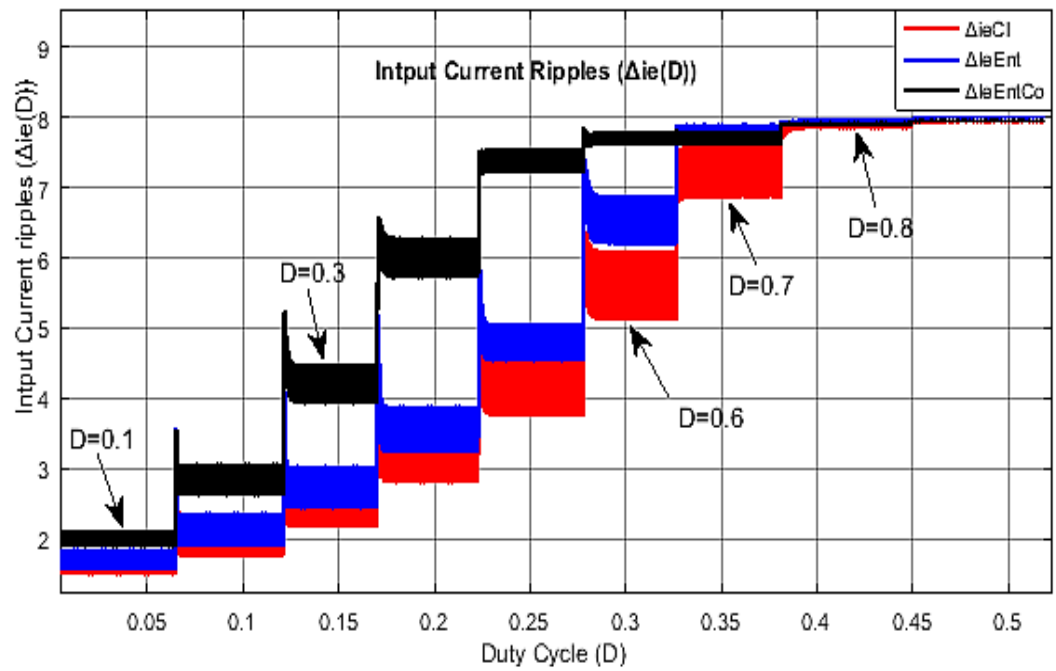

Figure 5. Input current ripple $\Delta \mathrm{ie}_{\mathrm{Pv}}$ of classical and interleaved boost with coupled and independent inductances with $0.1<\mathrm{D}<0.9$ and $\mathrm{X}=0.5$

The input current ripple of the interleaved Boost converter, with independent inductors $\Delta \mathrm{ie}_{\mathrm{Ent}}$, is small compared to that of the conventional Boost $\Delta \mathrm{ie}_{\mathrm{Cl}}$ for the same value of the inductance L. Likewise, the ripple of the input currents $\Delta \mathrm{ie}_{\mathrm{EntCo}}$ of the coupled interleaved Boost is considerably minimized compared to that of the interleaved Boost with independent inductors of $\frac{1}{1+K}$.

\subsection{Ripple of the Output Voltage $\Delta \mathrm{Vs}$}

In Figure 6, we compared by simulation, the ripple of the output voltage across the load of a conventional Boost converter compared to that of the interleaved Boost, with and without coupling of the inductors, for the same value of the output capacitance Cs for different values of the duty cycle D, similar to MPPT command, with shift commands $\mathrm{X}=0.5$.

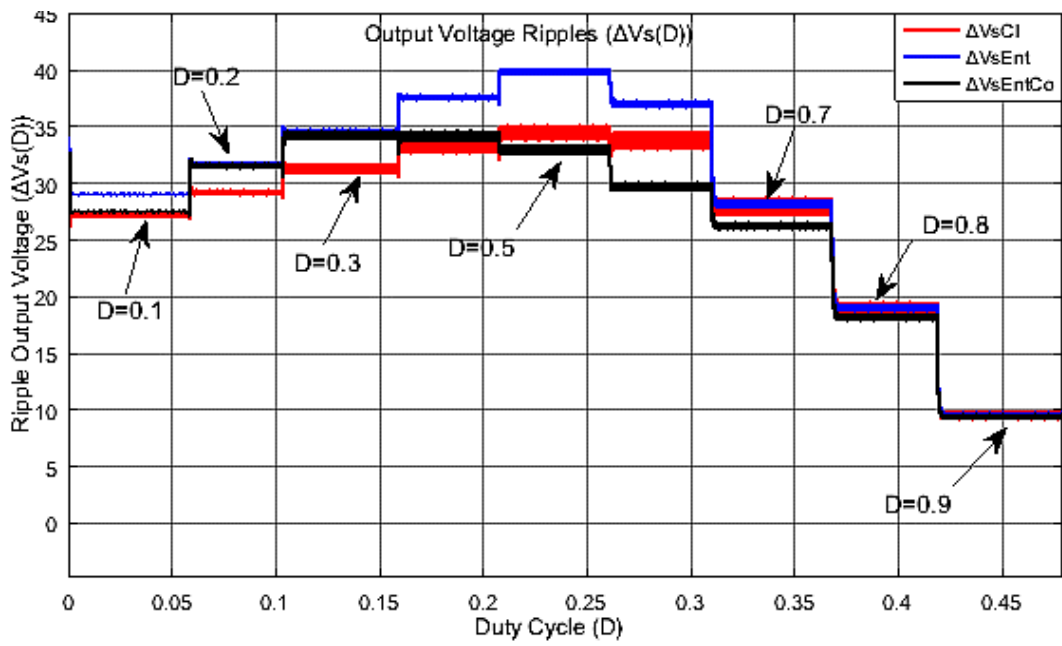

Figure 6. Output voltage ripple $\Delta \mathrm{Vs}$ of the classical and interleaved boost with coupled and independent inductances with $0.1<\mathrm{D}<0.9$ and $\mathrm{X}=0.5$ 
The interleaving of Boost converter minimizes the ripple of the output voltage $\Delta \mathrm{Vs}_{\mathrm{Ent}}$ compared to

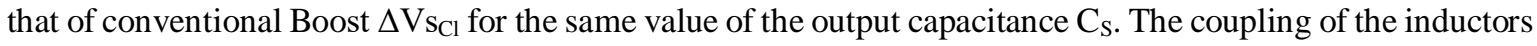
does not allow any gain in terms of ripple of the output voltage $\Delta \mathrm{Vs}_{\text {Entco. }}$.

\subsection{Maximizing the Power Extracted from the PV}

In this part, we measure, by simulation, the extracted power of the PV, associated with a conventional and interleaved Boost, with coupled and independent inductances, for different values of the duty cycle D and the commands shift coefficient X [1], [3].

Then, for each value of the duty cycle $\mathrm{D}$, we determine $\mathrm{X}$, which corresponds to the maximum power

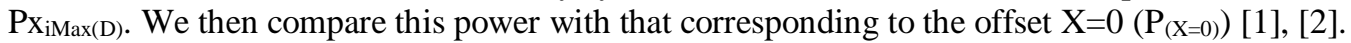

Figure 7 illustrates the comparison by simulation of the power extracted from PV panel, between the two topologies of Boost converters, conventional and interleaved with and without coupling of the inductances, for different values of the duty cycle $\mathrm{D}$ with $\mathrm{X}=0.5$.

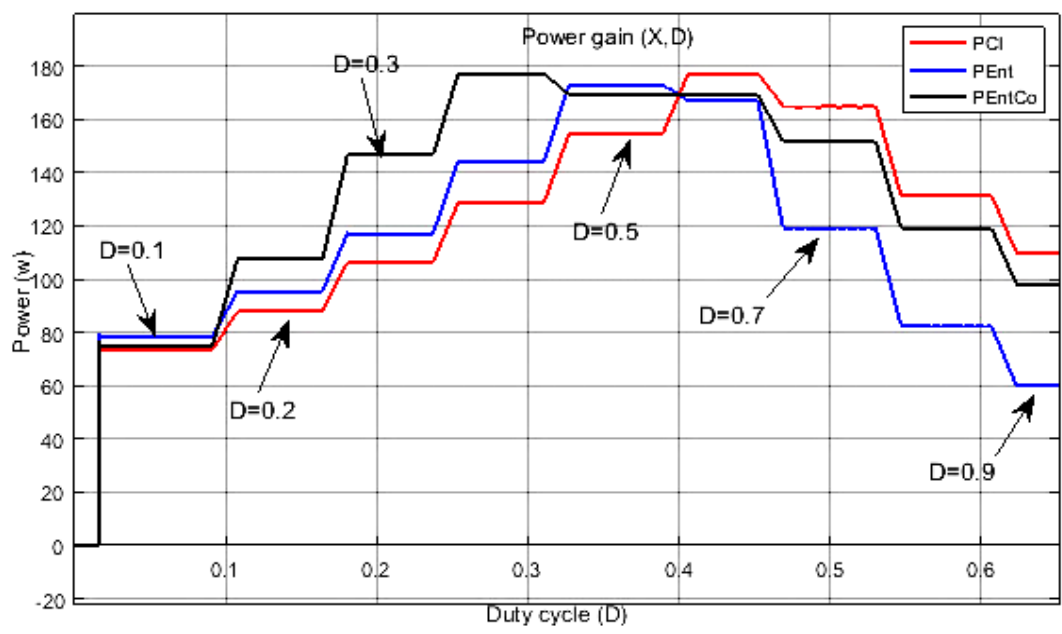

Figure 7. Power as a function of duty cycle D with $\mathrm{X}=0.5$

The interleaving of the Boost converters with shift of the commands maximizes the power extracted from the photovoltaic panels. The inductances coupling approach maximizes more this power.

In Figure 8 we compared by simulation, the power gain $\Delta \mathrm{P}_{\mathrm{X}(\mathrm{D})}$ extracted from the $\mathrm{PV}$ connected to an interleaved Boost converter, with independent and coupled inductances $\left(\Delta \mathrm{P}_{\mathrm{X}(\mathrm{Ent} / \mathrm{Cl})}, \Delta \mathrm{P}_{\mathrm{X}(\mathrm{EntCo} / \mathrm{Cl}) \text {, compared to a }}\right.$ conventional Boost, according to the duty cycle D.

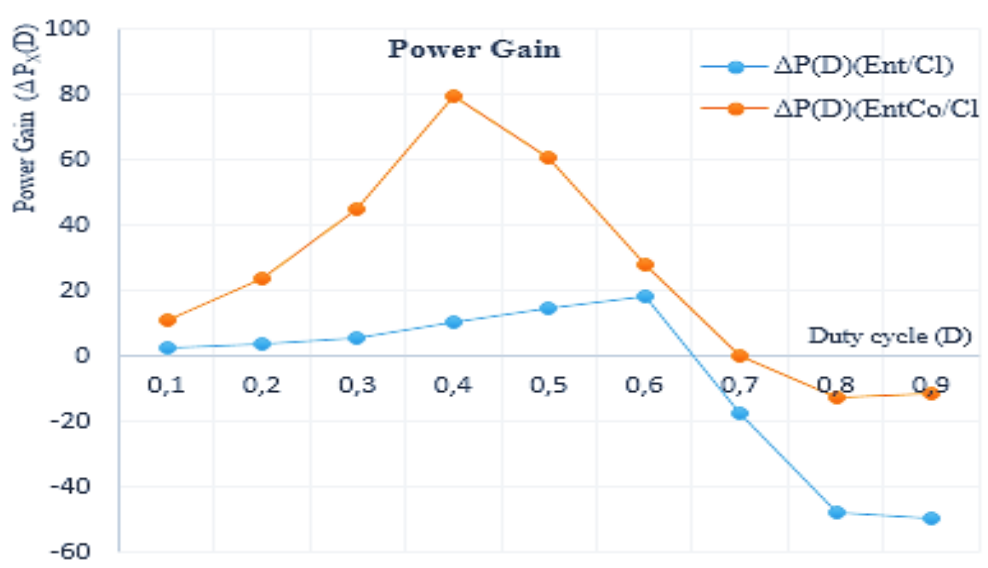

Figure 8 . Power gain $\Delta \mathrm{P}_{\mathrm{X}}(\mathrm{D})$ 
The power, extracted from the panel connected to an interleaved Boost converter with independent inductances, is higher than that extracted from a PV connected to conventional Boost converter for $\mathrm{D}<0.6$. The coupling of the inductances, significantly increases this power gain $\Delta \mathrm{P}_{(\mathrm{X})}$ by adopting an appropriate command shift X.

\section{EXPERIMENTAL RESULTS}

In order to validate the simulation results, we measured by experience, the ripple of the input currents $\Delta \mathrm{i}_{\mathrm{e}}$ of the two topologies, classical and interleaved Boost converters with independent and coupled inductors. Figure 9 shows the converter circuit, connected to a DC voltage source. The measurement parameters are shown in Table 2.

Table 2. Measurement System Parameters

\begin{tabular}{cc}
\hline System Parameters & Values \\
\hline Input voltage $\left(\mathrm{V}_{\mathrm{e}}\right)$ & $15 \mathrm{~V}$ \\
Switching frequency $(\mathrm{f})$ & $13.5 \mathrm{KHz}$ \\
Load $(\mathrm{R})$ & $20 \Omega$ \\
Output capacitance $(\mathrm{Cs})$ & $220 \mu \mathrm{F}$ \\
Inductors $\left(\mathrm{L}_{1}=\mathrm{L}_{2}=\mathrm{L}\right)$ & $433.47 \mu \mathrm{H}$ \\
Coupling coefficient $(\mathrm{K})$ & 0.93 \\
Shift coefficient $(\mathrm{X})$ & 0.5 \\
\hline
\end{tabular}

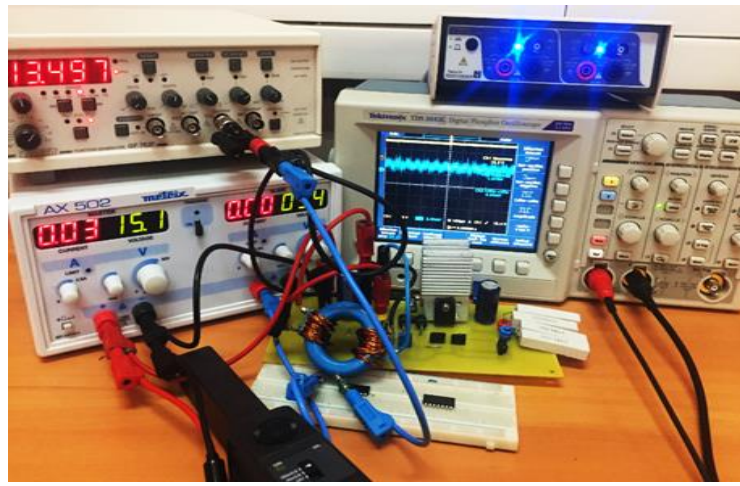

Figure 9. Measurement setup of the classic and interleaved boost

In Figure 10, we measured the input voltage $\mathrm{Ve}_{\mathrm{Cl}}$, input current $\mathrm{ie}_{\mathrm{Cl}}$ and its ripple $\Delta \mathrm{ie}_{\mathrm{Cl}}$, of the conventional Boost converter.

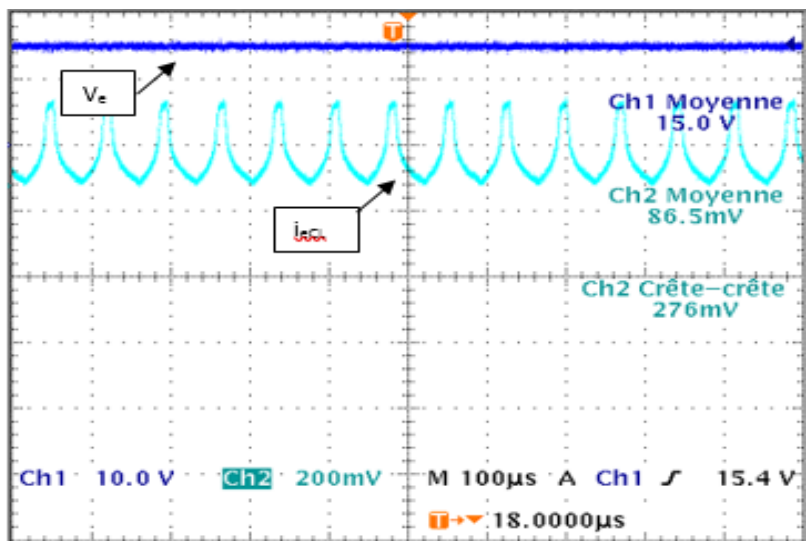

Figure 10. Input voltage Ve and current $\Delta \mathrm{ie}_{\mathrm{Cl}}$ of the classical boost, with $\mathrm{D}=0.5$ and $\mathrm{X}=0.5$ 
We have the ripple of the input current $\Delta \mathrm{ie}_{\mathrm{Cl}}=0.276 \mathrm{~A}$.

Figure 11 illustrates by measurement the input voltage $\mathrm{Ve}_{\mathrm{Ent}}$, input current ie $\mathrm{ent}_{\mathrm{En}}$ and its ripples $\Delta \mathrm{ie}_{\mathrm{Ent}}$ of the interleaved Boost without coupling.

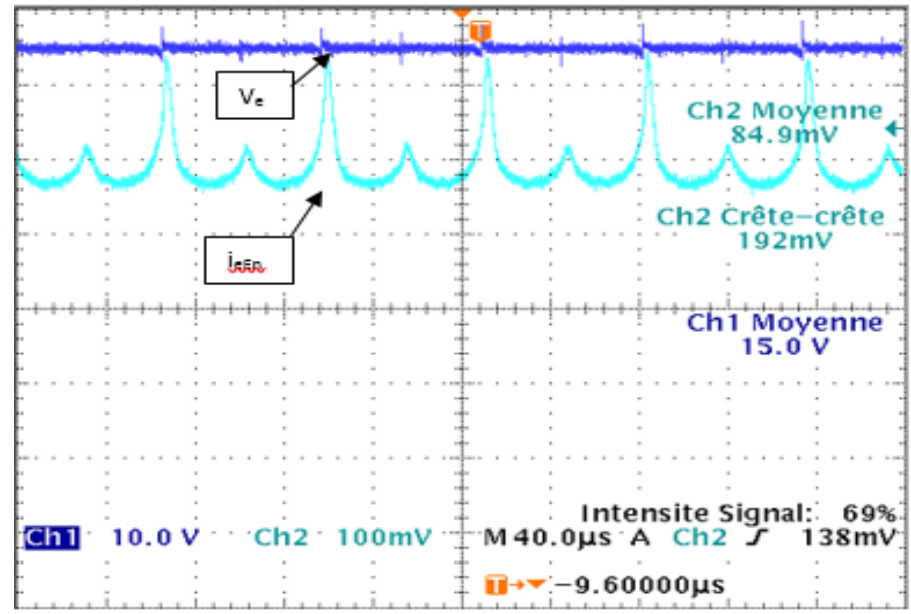

Figure 11. Input voltage Ve and current ie $\mathrm{Ent}_{\mathrm{f}}$ of the interleaved boost

We have the ripple of the input current $\Delta \mathrm{ieEnt}=0.192 \mathrm{~A}$. We will therefore have according to the measurements $\frac{\Delta \mathrm{ieE} n t}{\Delta \mathrm{ieCl}}=68 \%$.

The interleaving of the classic Boost converter with command shift, minimizes the ripples of the input current $\Delta$ ie. Figure 12 illustrates by measurement, the input voltage $\mathrm{Ve}_{\mathrm{EntCo}}$, and input current $\mathrm{ie}_{\mathrm{EntCo}}$ of the coupled interleaved Boost.

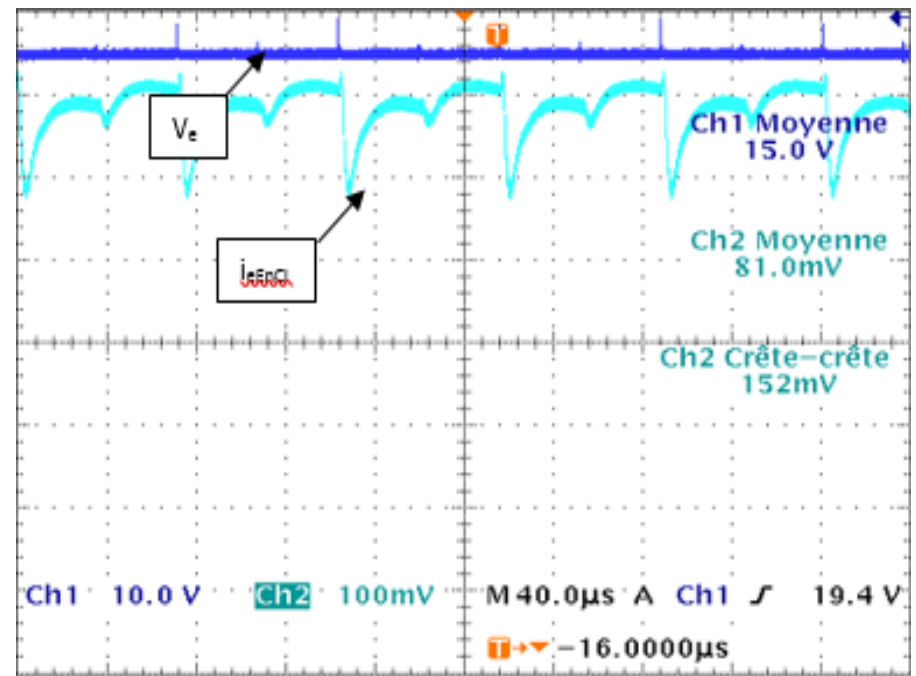

Figure 12. Input voltage $V e$ and input current $i_{\text {EntCo }}$ of the coupled interleaved boost with $\mathrm{D}=0.5$ and $\mathrm{X}=0.5$

We have the ripple of the input current $\Delta \mathrm{ie}_{\mathrm{EntCo}}=0.152 \mathrm{~A}$. We will therefore have according to the measurements $\frac{\Delta \mathrm{ieE} n t C o}{\Delta \mathrm{ieEnt}}=78 \%$.

The inductances coupling approach of interleaved Boost and the shift of the command minimizes the ripple of the input current $\Delta \mathrm{ie}_{\mathrm{EntCo}}$ compared to that of the interleaved Boost with independent inductors $\Delta \mathrm{ie}_{\mathrm{Ent}}$. 
Figure 13 shows by measurement, the output voltage $\mathrm{Vs}_{\mathrm{s}}$ and its ripples $\Delta \mathrm{V}_{\mathrm{SC} 1}$ of the conventional Boost converter.

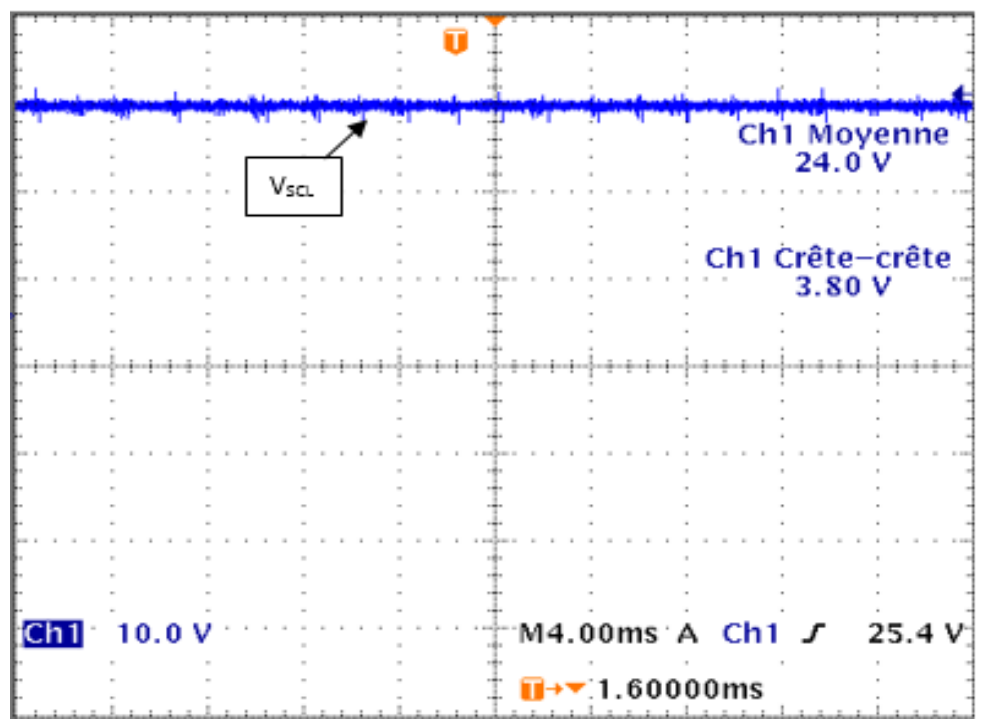

Figure 13. Output voltage $\mathrm{Vs}_{\mathrm{Cl}}$ of the classical boost with $\mathrm{D}=0.5$ and $\mathrm{X}=0.5$

We have the ripple of the output voltage $\Delta \mathrm{Vs}_{\mathrm{Cl}}=3.8 \mathrm{~V}$.

Figure 14 illustrates by measurement, the output voltage $\mathrm{Vs}$ with its ripple $\Delta \mathrm{V}_{\mathrm{SEnt}}$ of the interleaved Boost converter.

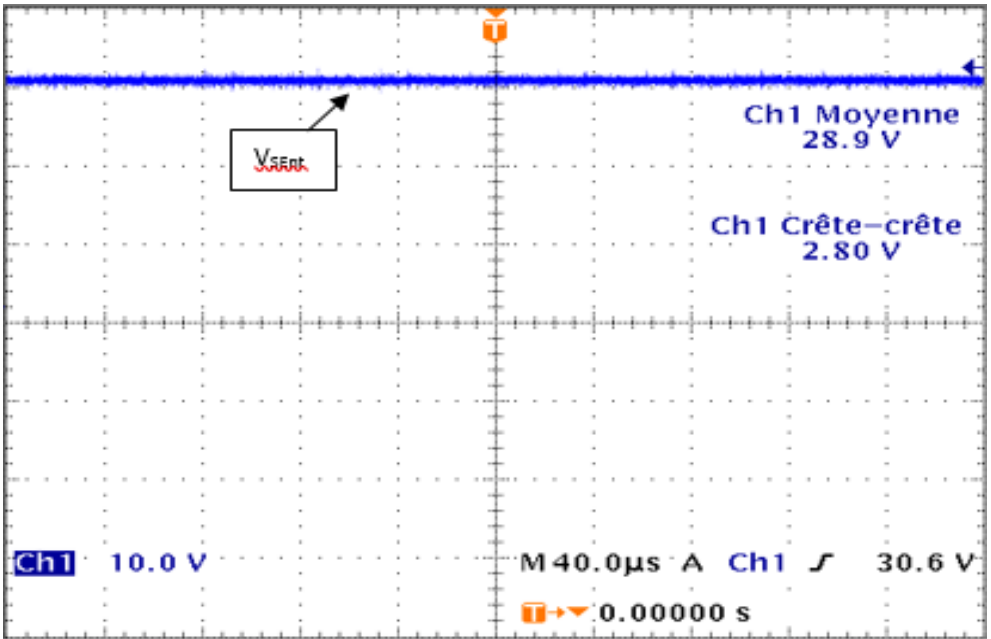

Figure 14. Output voltage Vs and, of the interleaved boost with $\mathrm{D}=0.5$ and $\mathrm{X}=0.5$

We have the ripple of the output voltage $\Delta \mathrm{VS}_{\mathrm{Ent}}=2.8 \mathrm{~V}$.

According to the measurements, we therefore have $\frac{\Delta \mathrm{VsE} n t}{\Delta \mathrm{VsCl}}=73 \%$. The interleaving of the classic Boost and the shift of the command, minimizes the ripples of the output voltage $\Delta \mathrm{Vs}$.

Figure 15 illustrates by measurement, the output voltage $\mathrm{Vs}$ and its ripples $\Delta \mathrm{Vs}_{\mathrm{EntCo}}$ of the interleaved Boost converter with coupling of the inductors. 


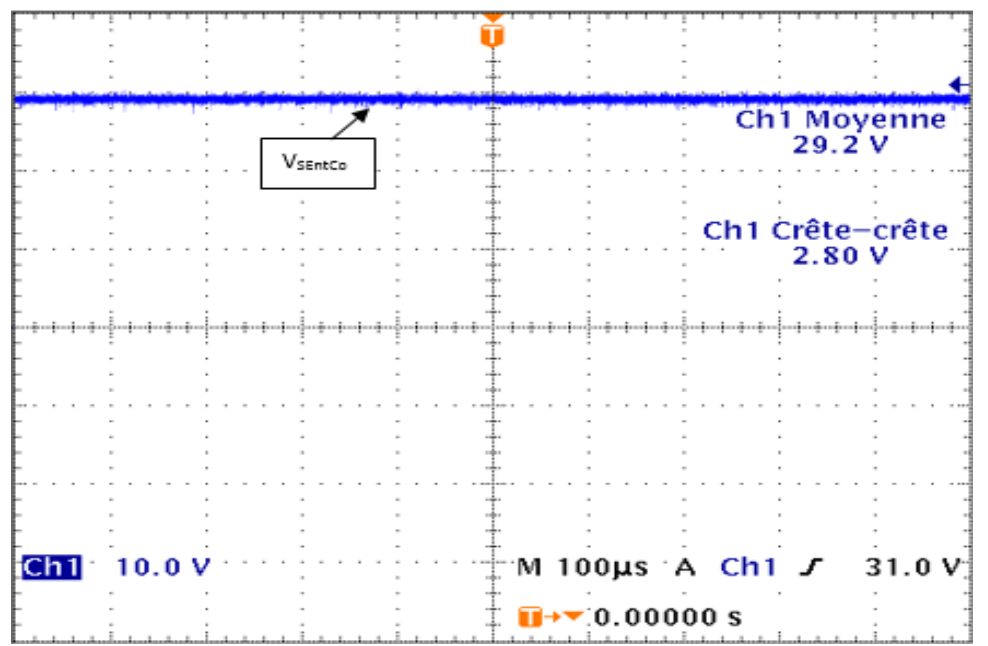

Figure 15. Output voltage Vs of the coupled interleaved boost with $\mathrm{D}=0.5$ and $\mathrm{X}=0.5$

We have the ripple of the output voltage $\Delta \mathrm{VsEntCo}=2.8 \mathrm{~V}$.

We therefore have, according to the measurements $\frac{\Delta \mathrm{VsE} n t \mathrm{Co}}{\Delta \mathrm{VEnt}}=73 \%$.

The interleaving approach of converters, with shift of the commands, minimizes the ripples of the output voltage. However, the coupling of the inductors does not allow any gain in terms of output voltage undulations $\Delta \mathrm{V}_{\mathrm{S} \text { EntCo. }}$

\section{CONCLUSION AND PERSPECTIVES}

In this paper, we compare, by simulation and measurement, two topologies of conventional and interleaved Boost DC/DC converters, in terms of input currents and output voltages, the size of the converter components and the power extracted from photovoltaic panels:

a. The currents in the components of the interleaved Boost converter, compared to the conventional Boost, are considerably reduced. As a result, the components (inductors, switches and capacitors of the converter) are miniaturized.

b. The ripples of the input currents and the output voltage of the interleaved converters are small compared to those of the conventional Boost converter.

c. The power extracted from the photovoltaic panel depends on the duty cycle D and the shift of the power switch commands.

d. Interleaved Boost inductances coupling, further reduces the ripples of the input currents and maximizes more, the power extracted of the PV.

e. The quality of the extracted power is improved in terms of ripples and value.

\section{REFERENCES}

[1] B. Lagssiyer, S. Zouggar and M. E. Hafyani, "Modeling and maximizing extracted PV power by converter boost interlaced,"2015 3rd International Renewable and Sustainable Energy Conference, Marrakech, 2015, pp. 1-6.

[2] B. Lagssiyer, S. Zouggar and M. El Hafyani, "Modelling of the Magnetic Couplers in High Frequencies Dedicated to the Photovoltaic Panels," 2017 International Renewable and Sustainable Energy Conference (IRSEC), Tangier, Morocco, 2017, pp. 1-10.

[3] Brahim L., Abdelhak A., El Hafyani M. (2019) Interleaved Positive Buck-Boost Converter (I.P.B.B). In: Hajji B., Tina G., Ghoumid K., Rabhi A., Mellit A. (eds) Proceedings of the 1st International Conference on Electronic Engineering and Renewable Energy. ICEERE 2018. Lecture Notes in Electrical Engineering, vol 519. Springer.

[4] V. Vasudevan and K. Balaji, "Performance of Cuk-KY Converter Fed Multilevel Inverter for Hybrid Sources," Indonesian Journal of Electrical Engineering and Computer Science, vol. 10, no. 2, pp. 2018.

[5] G. S. Rao, et al., "Design of Feedback Controller for Boost Converter Using Optimization technique," International Journal of Power Electronics and Drive System (IJPEDS), vol/issue: 3(1), pp. 117 128, 2013.

[6] Waleed Ishaq Hameed, Baha Aldeen Sawadi, Ali Muayed Fadhil, "Voltage Tracking Control of DC- DC Boost Converter Using Fuzzy Neural Network," International Journal of Power Electronics and Drive System (IJPEDS) Vol. 9, No. 4, pp. 1657 1665, December 2018. 
[7] J. D. Navamani, et al., "Analysis of modified quadratic DC-DC boost converter," IEEE International Conference on Inventive Systems and Control (ICISC), pp. 1-5, 2017.

[8] Santhosh T.K. and Govindaraju C., "Development of Predictive Current Controller for Multi-Port DC/DC Converter," International Journal of Power Electronics and Drive Systems (IJPEDS), vol/issue: 6(4), pp. $683-692,2015$.

[9] A. B. Ponniran, K. Orikawa, and J. i. Itoh, "Interleaved high boost ratio Marx topology DC-DC converter," in 2015 IEEE 2nd International Future Energy Electronics Conference (IFEEC), pp. 1-6, 2015.

[10] R N. Kumar, "Energy Management system for Hybrid RES with Hybrid Cascaded Multilevel inverter," International Journal of Electrical and Computer Engineering (IJECE), vol/issue: 4(1), pp. 24-30, 2014.

[11] M. Kavitha and V. Sivachidam baranathan, "Comparison of Different Control Techniques for Interleaved DC-DC Converter," International Journal of Power Electronics and Drive System (IJPEDS), 9(2), pp. 641-647, 2018.

[12] Bhat S, Nagaraja HN. "Effect of Parasitic Elements on the Performance of Buck-Boost Converter for PV Systems". International Journal of Electrical and Computer Engineering, 4(6): 831-836, 2014.

[13] S. Dasam and B. V. Sankerram, "Voltage Balancing Control Strategy in Converter System for Three-Level Inverters,"International Journal of Electrical and Computer Engineering (IJECE), vol/issue: 3(1), pp.7-14, 2013.

[14] A. N. Kasiran and A. Ponniran and M. A. Harimon and H. H. Hamzah, "A Study of 4-level DC-DC Boost Inverter with Passive Component Reduction Consideration,” J. Phys. Conf. Ser., vol. 995, no. 1, p. 12062, 2018.

[15] A. Ponniran, K. Orikawa, and J. Itoh, "Fundamental Operation of Marx Topology for High Boost Ratio DC-DC Converter," IEEJ J. Ind. Appl., vol. 5, no. 4, pp. 329-338, 2016.

[16] Vanitha D and M. Rathinakumar, "Fractional Order PID Controlled PV Buck Boost Converter with Coupled Inductor," International Journal of Power Electronics and Drive System (IJPEDS), 8(3), pp. 1401-1407, 2017.

[17] N. Hashim, and al., "DC-DC Boost Converter Design for Fast and Accurate MPPT Algorithms in Stand-Alone Photovoltaic System,” International Journal of Power Electronics and Drive System (IJPEDS), 9(3), pp.1038-1050, September 2018.

[18] L. N. Rao, and al., "Design of DC-DC Boost Converter with Negative Feedback Control for Constant Current Operation," International Journal of Power Electronics and Drive System (IJPEDS), 8(4), pp. 1575 1584, 2017.

[19] Girish Ganesan R. Dr.M.Prabhakar, "Non-Isolated High Gain Boost Converter for Photovoltaic Applications", ICPEC-2013, IEEE, pp. 271- 280.

[20] S.S.Muley, R.M.Nagarale, "Sliding Mode Control of Boost converter," IJETAE, vol.3, Issue 9, Sept.2013.

[21] V. Ramesh, Y. Kusuma Latha, "An Interleaved Boost Converter Based PFC Control Strategy for BLDC motor," International Journal of Electrical and Computer Engineering (IJECE), Vol. 5, No. 5, pp. 957 966, October 2015.

[22] Yang, W. Li, Y. Zhao, and X. He, "Design and analysis of a grid connected PV power system", IEEE Trans.Power Electron., vol. 25, no. 4, pp. 992-1000, Apr. 2010.

[23] M. Mousa, M. Ahmed and M. Orabi, "A switched inductor multilevel boost converter," 2010 IEEE International Conference on Power and Energy, Kuala Lumpur, pp. 819-823, 2010.

[24] Y. R. J. Wai and R. Y. Duan, "High step-up converter with coupled inductor", IEEE Trans. Power Electron., vol.20, no. 5, pp. 1025-1035, Sep. 2005.

[25] M. Pavlovsk'y, G. Guidi, and A. Kawamura, "Assessment of coupled and independent phase designs of interleaved multiphase buck/boost DC-DC converter for EV power train," IEEE Trans. Power Electronics, vol. 29, no. 6, pp. 2693-2704, December 2014. 